\title{
PHOTOGRAMMETRIC MODELLING FOR URBAN MEDIEVAL SITE MAPPING. A CASE STUDY FROM CURTEA DE ARGEŞ, ROMANIA
}

\author{
Constantin Nistor ${ }^{1}$, Bogdan Mihai ${ }^{1}$ Liviu Toma ${ }^{2}$, Irina Carlan ${ }^{3}$ \\ ${ }^{1}$ Faculty of Geography, University of Bucharest, Romania \\ ${ }^{2}$ Department of Geomorphology, University of Bucharest/GISBOX SRL, Romania \\ ${ }^{3}$ Department of Regional Geography, University of Bucharest, GISBOX SRL, Romania
}

Manuscript received: April 26, 2017

Revised version: July 02, 2017

\begin{abstract}
Nistor C., Mihai B., Toma L., Carlan I., 2017. Photogrammetric modelling for urban medieval site mapping. A case study from Curtea de Argeş, Romania. Quaestiones Geographicae 36(3), Bogucki Wydawnictwo Naukowe, Poznań, pp. 87-96. 10 figs.

AвSTRACT: Detailed mapping of urban historical sites superposed on natural landforms within built-up areas is a real challenge. Digital photogrammetric techniques meet the requirements for mapping archaeological sites within dense built-up areas. The objectives are to reveal the landform value in medieval site development and to analyse its impact on the landforms. The aim of the present study is to highlight the contribution of geomatics technologies for the evaluation and preservation of historical sites using UAV (Unmanned Aerial Vehicle) imagery and field photos for 3D modelling. Curtea de Argeş medieval site, established on Argeş River terraces and attested since the $13^{\text {th }}$ century, represents the town core for which the specific methodology was applied.
\end{abstract}

KEY wORDS: urban historical site, UAV photogrammetric flight, Curtea de Argeş, 3D modelling

Corresponding author: Irina Carlan, irina.carlan@gisbox.ro

\section{Introduction}

Urban development was marked by landscape changes and intensive transformations of topographic features along centuries (Del Monte et al. 2016, Pica et al. 2016). A lot of rock outcrops and a large spectrum of landforms of scientific interest are partially or totally covered by buildings and specific infrastructures like street networks (Serrano, Ruiz-Flaño 2009, De Wever et al. 2016). There are only few exceptions, mostly from the regions with sharp morphological contrasts like the towns around fortresses on rock outliers (Clivaz, Reynard 2017). Several scientific papers focused on the importance of historical sites, most of them having a chronological significance in the context of urban development along centuries (Rodrigues et al. 2011, Del Lama et al. 2015, Erikstad et al. 2017). Historical aerial images have a great contribution for monitoring topography changes due to anthropic factors (Scardozzi 2010, Doering et al. 2012), for tracking land cover changes (Ruan, Ellis 2004, Jao et al. 2014), for archaeological site studies (Stichelbaut 2006) and for monitoring urban sprawl (Dadras et al. 2014, Nebiker et al. 2014, Mihai et al. 2016). 
Besides the importance for urban planning, historical sites have a huge potential for urban tourism and education (Pinto et al. 2011, Adriansyah et al. 2015). This is marked by the increase of advertisement using the media channels from simple descriptive panels to mobile applications targeting the historical sites (Martin et al. 2014, Pelfini, Bollati 2014, Pica et al. 2016, 2017).

The challenge for landform analysis and historical site mapping comes from the superposition of urban structures and facilities on a topographic background with an intensive anthropic transformation (Chan, Godsey 2016). Given the complex pattern, an integrated approach based on geomorphology and archaeology is needed.

The current approach is focused on Curtea de Argess site, emphasizing the contribution of geomatics technologies for old architectural reconstruction and evaluation. Within the historical site, we completed a detailed analysis for Princely Church, whose value is derived from its architecture and old interior paintings which act as veridic mural documents describing people's lifestyle, historical events and portraits of past leaders. Moreover, we expand the importance of the historical site using state-of-the-art multimedia products. The main objective of the present study is to highlight the landform value in medieval site development and its imprint on topography and to exploit the potential of 3D modelling for historical site preservation, promotion and monitoring.

This methodology reveals and maps the geomorphologic setting and archaeological landmark of Curtea de Argess medieval site, in the context of urban development in the last 50 years. This is achieved by the integration of UAV (Unmanned Aerial Vehicle) imagery with field photos for 3D modelling and historical aerial images.

\section{Study area}

Curtea de Argeş medieval site was first documented in the $13^{\text {th }}$ century (Curinschi 1967) and is located South of the Carpathians, in the hilly area of the Getic Piedmont on Argess River Valley (Fig. 1). The altitude varies between 400 and $460 \mathrm{~m}$ a.s.l. and corresponds to the outlier of fluvial terraces, characterized by steep slopes. The site was founded as a Princely Church (Rom. Curtea Domnească) and is attested by archaeological evidences in 1290 and in 1330 AD, as the Capital of Wallachia (Constantinescu 1984) and later in 1510, the town is mentioned in documents under this name. The first iconographic representation dates from 1840 (Bouquet 1843). Archaeological and historical research campaigns in 1919 and between 1960 and 1970 revealed the importance of this Princely Court, which was included in the Romanian UNESCO World Heritage indicative list in 1991.

The historical site is located on the second terrace of Argeş River with 15-20 m relative altitude (Sandu 2008). The geomorphological map shows the topography of an outlier divided by an inactive gully, which is nowadays used as a main street (Fig. 2).

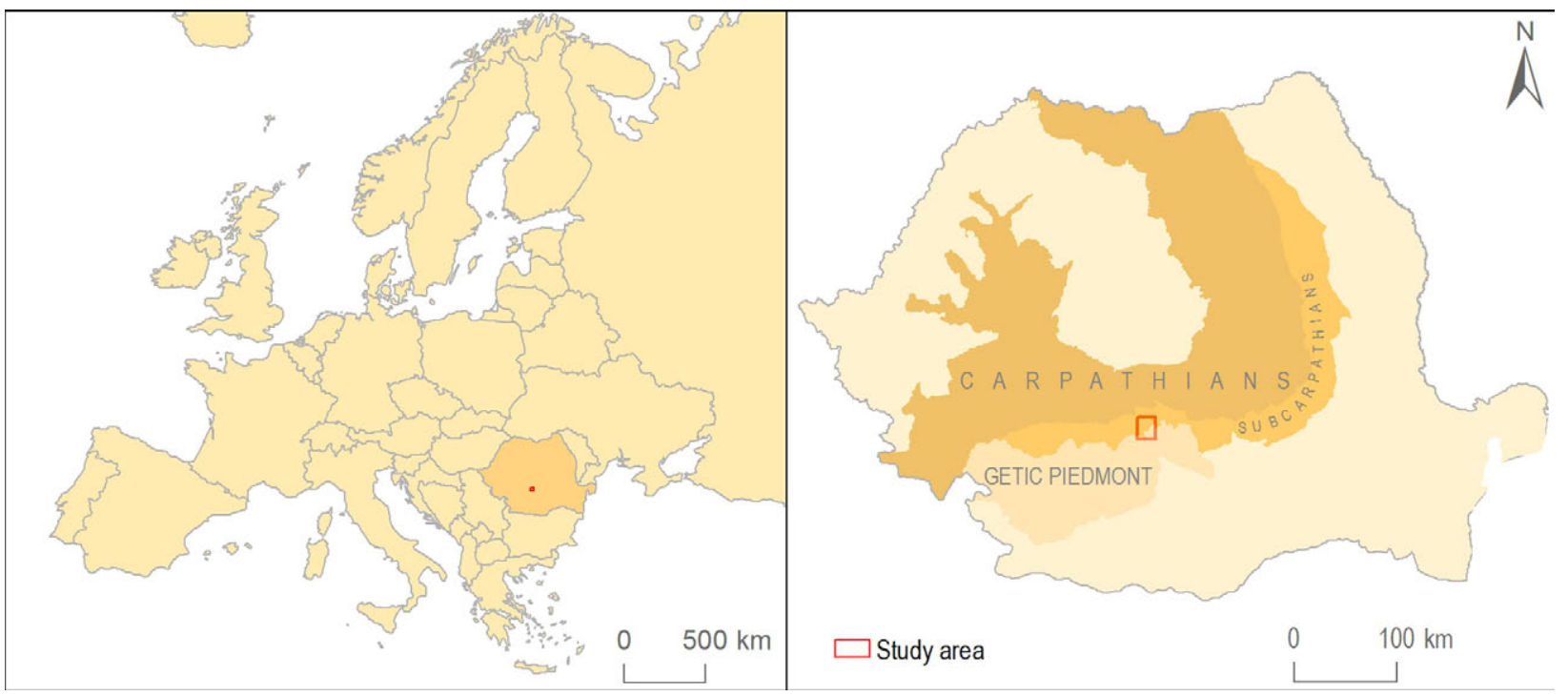

Fig. 1. Location of Curtea de Argeş historical site. 


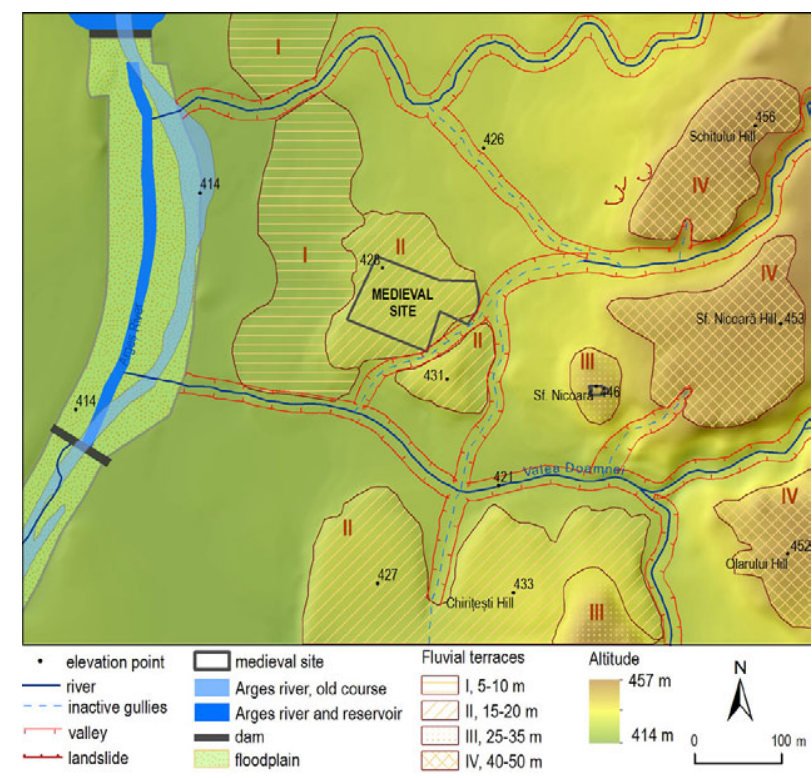

Fig. 2. Geomorphological map of the Curtea de Argeş medieval site area.

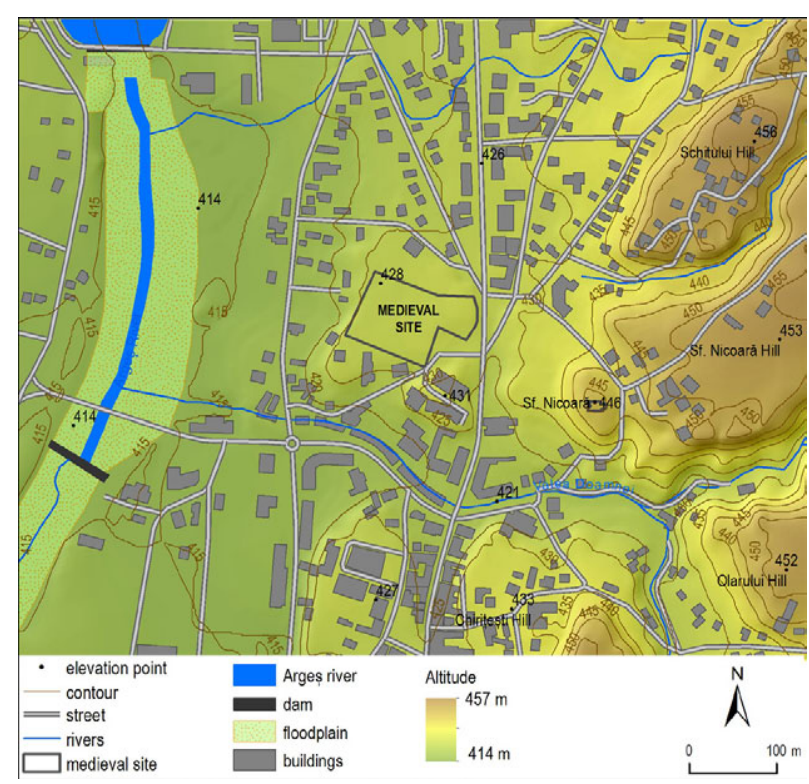

Fig. 3. Spatial distribution of built-up area around the historical site.
Starting with the second half of the $20^{\text {th }}$ century, the urban structures began to develop around the historical site and overcrowded the terrace outlier with houses and blocks of flats (Curinschi 1967, Osaci-Costache 1998). In the same period, the Argeş River floodplain changed from its natural regime to a totally anthropogenic configuration after the building of the first hydroelectric dam and reservoirs (Fig. 3). The industrialization of the town with a current population of 27,700 inhabitants had a peak in the 1980s, when the need for residential buildings was important. In this context, the topographic landmark was covered by built-up area, up to the medieval walls.

\section{Materials and methods}

Historical site mapping is an important and useful research topic, which expanded in the last period due to an increase of data amount from various sources. Detailed maps act as a digital representation of both natural and historical elements and they are now common as a result of data availability (Varga et al. 2015, Werle 2016). Within this new context, our approach tries to find a solution for an accurate and precise GIS mapping of the urban medieval site, using UAV photogrammetric techniques to reveal topographic and historical features. After a thorough investigation, we discovered that there is a limitation regarding available old data sources (Table 1 ).

The existing topographic maps with different scales and sources were georeferenced and used for vector data extraction: contour lines, landmarks, topographic features. Historical aerial images were inserted into a photogrammetric workflow in order to produce an orthophotomosaic with a uniform scale. The UAV flight campaign

Table 1. Data sources and derived outputs.

\begin{tabular}{|c|l|c|c|l|}
\hline No. & \multicolumn{1}{|c|}{ Dataset } & $\begin{array}{c}\text { Spatial resolution/ } \\
\text { Scale }\end{array}$ & Year & \multicolumn{1}{|c|}{ Data Source } \\
\hline 1. & Orthophotomosaic & $1 \mathrm{~m}$ & 1967 & $\begin{array}{l}\text { Historical aerial photos, Military Top- } \\
\text { ographic Directorate }\end{array}$ \\
\hline 2. & Topographic survey & $1: 1000$ & 1973 & Constantinescu, 1984 \\
\hline 3. & Archaeological survey & $1: 500$ & 1973 & Constantinescu, 1984 \\
\hline 4. & Cadastral maps & $1: 5000$ & 1984 & National Cartography Center \\
\hline 5. & $\begin{array}{l}\text { Orthophotomosaic, Digital Surface } \\
\text { Model, Point Cloud }\end{array}$ & $0.02 \mathrm{~m}$ & 2016 & UAV flight campaign \\
\hline 6. & Ground Control Points & - & 2016 & GPS survey \\
\hline 7. & Vector dataset & - & 2016 & Open Street Map \\
\hline
\end{tabular}


Table 2. Sensor properties and field campaign details.

\begin{tabular}{|c|c|c|c|c|}
\hline & & Sensor properties & \multicolumn{2}{|c|}{ Flight mission } \\
\hline \multirow{8}{*}{ 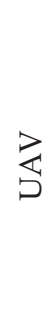 } & Model & Sony Alpha 6000 & UAV & Hexacopter \\
\hline & Lens mount & Sony E-Mount 16 mm F2.8 & Flight altitude & $90 \mathrm{~m}$ \\
\hline & Sensor resolution & 24 Megapixels & AOI surface & $0.5 \mathrm{ha}$ \\
\hline & Focal length & $16 \mathrm{~nm}$ & Resolution & $2.19 \mathrm{~cm}$ \\
\hline & Sensor size & $23.5 \times 15.6 \mathrm{~mm}(6000 \times 4000 \mathrm{px})$ & No. of frames & 122 \\
\hline & Sensor type & Simos & No. of strips & 10 \\
\hline & Internal camera pixel size & 3.92 microns & Image overlap & \\
\hline & & & Strip overlap & \\
\hline \multirow{3}{*}{$\begin{array}{l}\text { D } \\
\text { U }\end{array}$} & \multicolumn{2}{|c|}{ Sensor properties } & \multicolumn{2}{|c|}{ Field mission } \\
\hline & Model & Leica Viva GNSS GS14 & No. of GCPs & 22 \\
\hline & Correction & RTK ROMPOS & Precision & $\pm 5 \mathrm{~mm}$ \\
\hline
\end{tabular}

was done in September 2016 by GISBOX SRL, using a hexacopter carrying a SONY digital optic sensor at the altitude of $90 \mathrm{~m}$ above ground. The UAV flight lasted for approximately 17 minutes and covered an area of interest of about 0.5 ha, delivering 122 frames. The GPS field survey was undertaken in October 2016, when 22 Ground Control Points (GCP) were measured with millimetric precision (Table 2).

The historical aerial photos at about 1:10,000 scale, obtained from the archive of Military Topographic Directorate (DTM), were processed to an orthophotomosaic, useful for the documentation of the starting point of urban structural transformation within the master plan from 1965. This allowed us to track the changes over the landscape that has been subsequently transformed. The orthophotomosaic and the point cloud model generated from UAV images allowed us to extract current topographic and historical site features that were visualized in a three-dimensional perspective.

The proposed methodology integrates a photogrammetric workflow into the GIS mapping stages for the case study of Curtea de Argeş medieval town core (Fig. 4).

The photogrammetric workflow started with the archive of aerial imagery from 1967. The

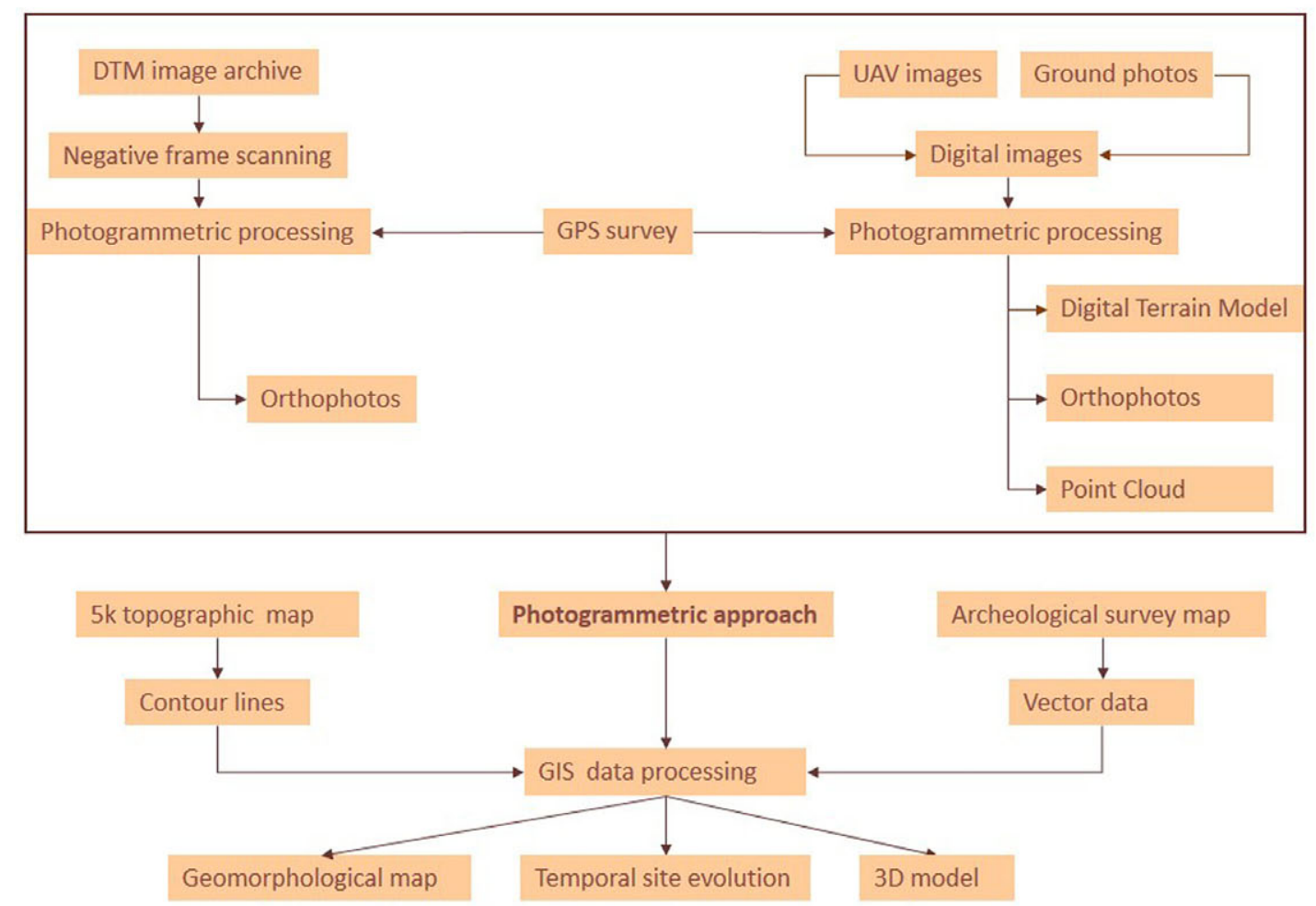

Fig. 4. Workflow chart methodology. 
analogical negative frames were transferred into a digital environment using a common flat scanner and then assembled using predefined grid tiles. The stereo-pair images were integrated in a typical photogrammetric processing chain (Mikhail et al. 2001) using Socet Set 5.4 by BAE Systems GXP, with the help of GCPs, collected from an independent data source: the orthophotomosaic from 2012 at $0.5 \mathrm{~m}$ spatial resolution, provided by the National Agency for Cadastre and Land Registration (ANCPI). The custom camera model and GCPs helped us to solve both interior and exterior orientation for photogrammetric block and then to construct an aerial triangulation model for bundle adjustment. Using the Digital Elevation
Model (DEM), with a spatial resolution of $5 \times 5 \mathrm{~m}$, interpolated from vector contour lines digitized from 1:25,000 Military Topographic Maps (Table 1). The images were orthorectified and radiometrically adjusted in order to produce an orthophotomosaic for the reference year of 1967.

All the UAV frames were imported into ContextCapture v4 by Bentley Systems, a dedicated UAV photogrammetric software (Nex, Remondino 2014, Aicardi et al. 2016). The geotagged images were automatically aligned and adjusted with the help of GCPs collected on the field. The problem of interior orientation was solved with a predefined camera calibration file which describes the focal length and the image
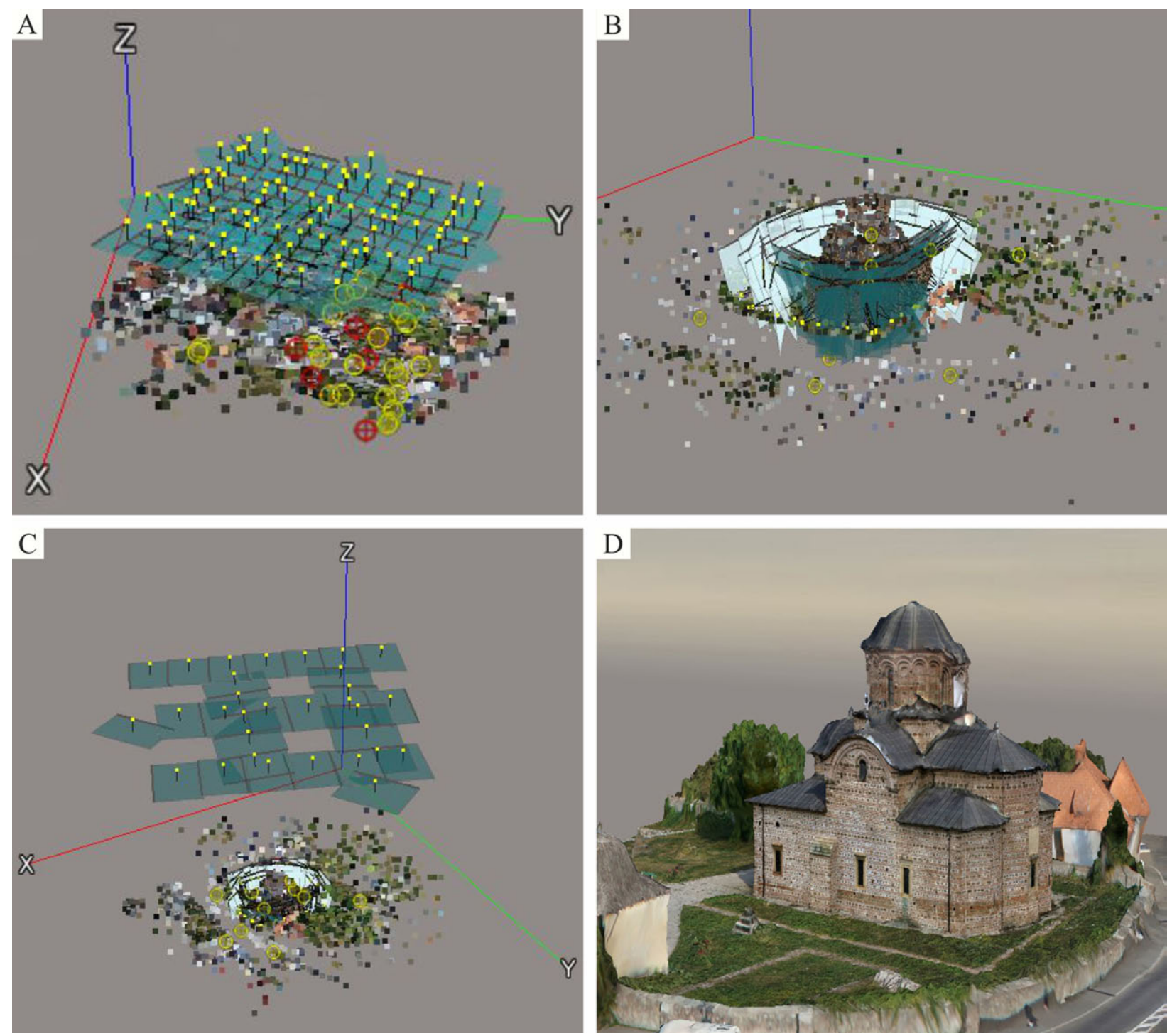

Fig. 5. Stages of production for UAV imagery and ground photos fusion in 3D modelling. A. Camera alignment and tie points co-registration. B. Ground photos alignment and pixel matching. C. UAV imagery and ground photos pixel matching. D. 3D modelling for Curtea de Argeş Princely Church. 
geometry. The aerial triangulation was constructed for the entire photogrammetric block with automatic tie points collection, which conducted us to the next step: point cloud generation. Points were automatically triangulated in order to produce a Triangulated Irregular Network (TIN), representing the mesh type model of the mapped surface. Further on, the Digital Surface Model (DSM) was generated and used for images orthorectification and DEM generation for the medieval site and its surrounding area.

The novelty of the approach is a double crossed photogrammetric flight, from which it is obtained a high dense point cloud, later imported as LiDAR data, for 3D landscape modelling and a better interpretation. Moreover, ground photos were integrated into a photogrammetric chain for 3D architecture reconstruction (Zarnowski et al. 2015, Cârlan, Dovleac 2017). We focused on the most important feature of the historical site, The Princely Church, which preserves byzantine architectural style, being the oldest from Wallachia. Consequently, due to complete image coverage from different view angles, a point cloud for the entire object was produced, improving its geometry and texture (Fig. 5).

The next level of the analysis was the GIS multisource data integration, together with the mapping of the site from Curtea de Argeş medieval town core. This integrates data from photogrammetric survey with ancillary datasets, such as topographic maps and the latest archaeological survey.

\section{Results and discussion}

Our approach leads to a series of results which consist in models and maps of the historical site covering a large temporal frame of 50 years. These products allow a complex characterization of the medieval site as a result of interrelationships between historical heritage and the topographic context (Reynard et al. 2017).

The results were quantified in four major outputs:

- a geomorphological map of the spatial features in and around the study site for the detection of landform significance (Fig. 2);

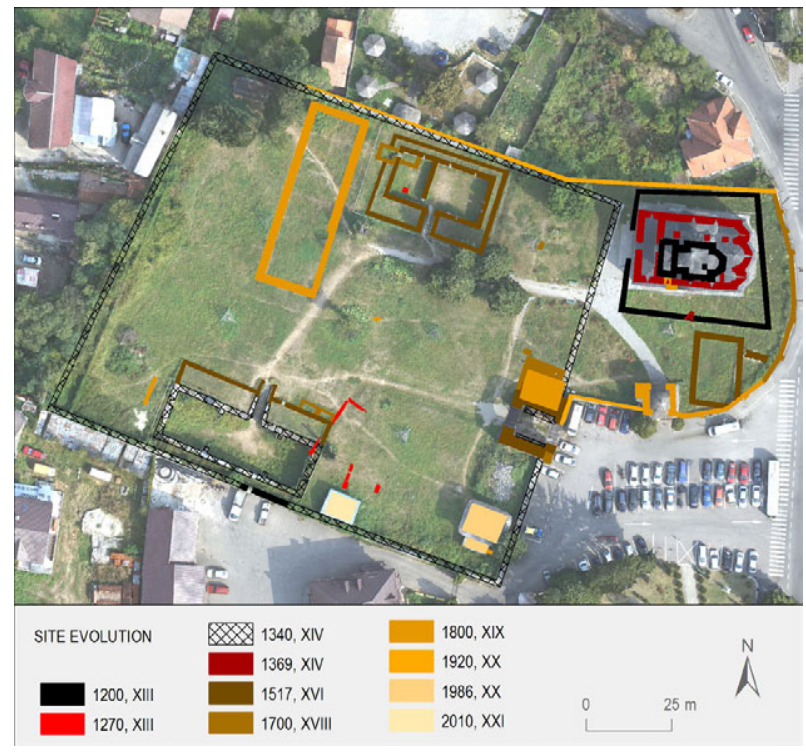

Fig. 6. Temporal evolution of the Princely Court site mapping with 2016 orthophotomosaic serving as basemap.

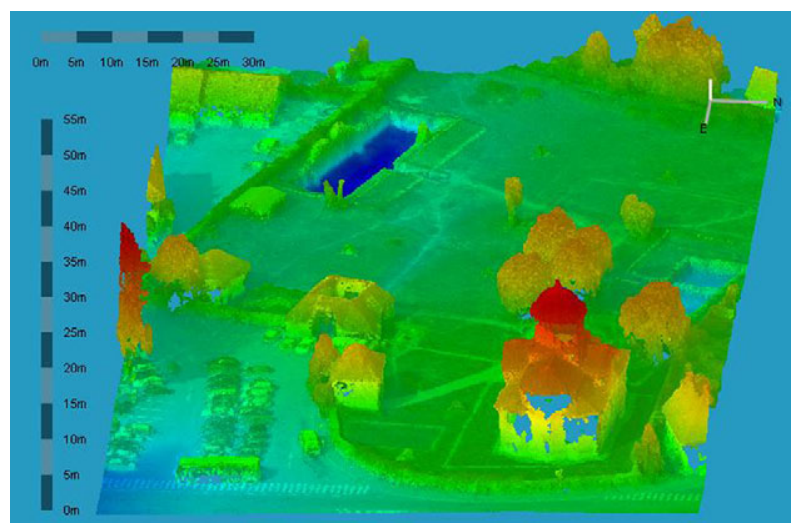

Fig. 7. Point cloud data represented by height for medieval site.

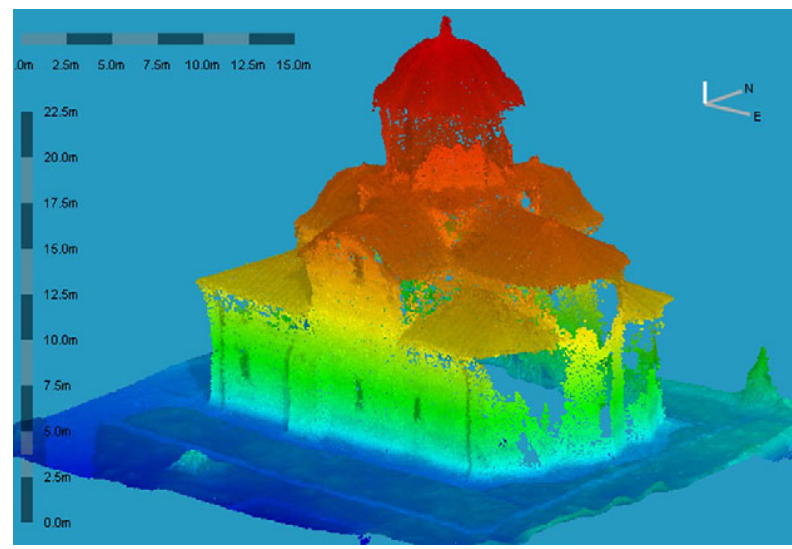

Fig. 8. Detailed point cloud classification by height for Curtea de Argeş Princely Church historical monument. 
- the updated mapping of the historical site, renewing the existing historical and archaeological medieval landmarks (Fig. 6);

- point cloud data for the entire medieval site (Fig. 7);

- a 3D textured model of the Princely Church within the historical site (Fig. 9).

Because the buildings cover the entire terrace outlier hill, the topography can only be interpreted based on the digital models. The DEM resulted from merged contour lines based on 1:1000 topographic survey from 1973 (Constantinescu 1984) and 1:5000 cadastral maps from 1984 helped the identification of the site location, hypsometry and micro-landforms pattern (Mandrut 1994, Sandu 1997). The medieval site has a strategic position
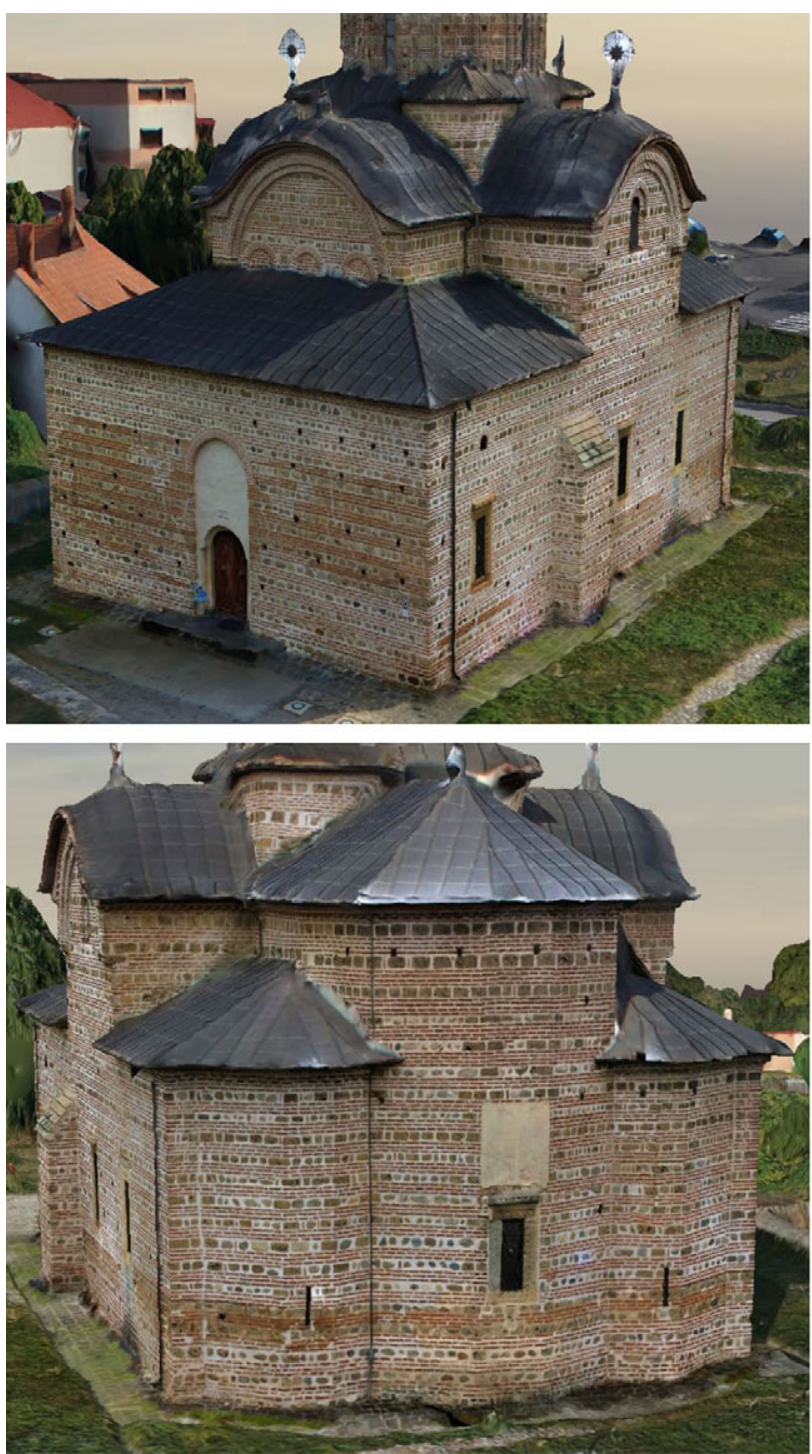

which exploited the topography. It is situated on the top of a hilly outlier from the second terrace between two major streams and gullies tributary to Argeş River (Fig. 2). Because of its favourable location, the Princely Court could not be destroyed nor damaged by natural disasters, being well preserved despite its extended lifetime for more than 700 years. We also mapped the changes in topography which occurred due to urban development and infrastructure increase (Fig. 3). It can be observed that the floodplain of Argeş River is now covered by a reservoir for hydro-electrical power. The previously existing valleys were removed or drastically changed. For example, Valea Doamnei stream, to the south of historical site, is now canalized and regulated,
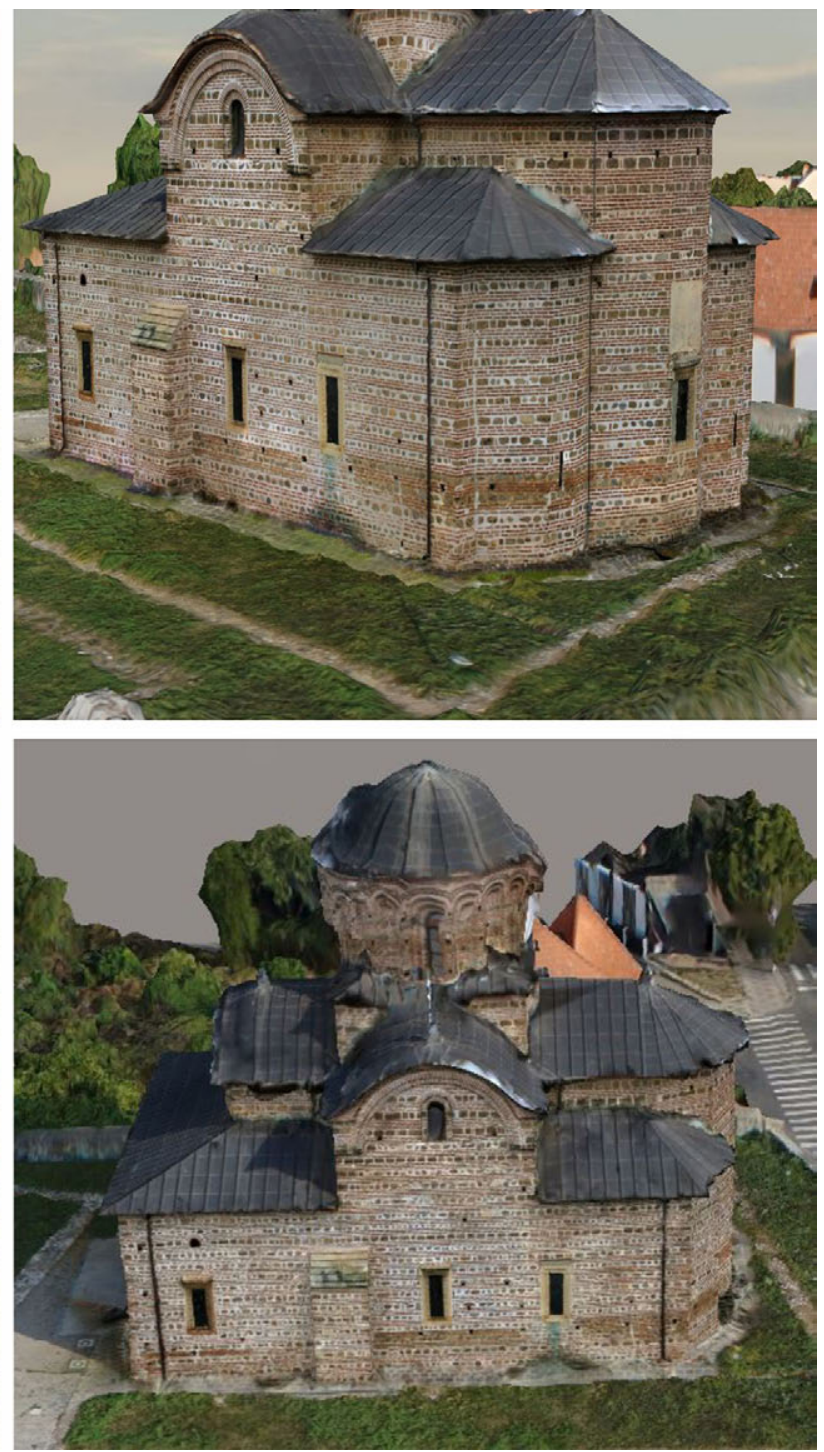

Fig. 9. 3D model with mesh and texture resulted from aerial imagery and ground photo fusion for Curtea de Argeş Princely Church. 
being covered by concrete walls and buildings. The gullies were totally removed from the topography, nowadays their ways offering support for the city street network (Fig. 3).

The resulted orthophotomosaic was integrated with previous existing studies (Constantinescu 1984) in GIS environment, for updating the historical landmark spatial database, in order to improve its consistency. It shows the spatial evolution where different generations of defence walls were adapted to the topographic configuration. The accurate orthophotomosaic of $0.02 \mathrm{~m}$ spatial resolution offers support for identifying the pattern of the medieval site, represented by the spatial distribution of imprints from old buildings (Fig. 6).

The point cloud for the entire Princely Court, interpreted as LiDAR data, was used for a 3D object reconstruction with complete physical characteristics and highlighting its impact on landforms (Fig. 7). This digital representation shows the site location on a fluvial morphological feature within to the edge of a terrace scarp. The steep slope associated with the scarp increases the landslide susceptibility in the western part of medieval site. The occurrence of this natural hazard damaged the stone walls and decreased the court's surface. In the same time, all the ground detail features could be interpreted as potential ruins, which may need archaeological investigation in the future.

The architectural style specific for medieval times and particularly for Walachia implied a fortified infrastructure that was used for living, defending and worshiping spaces. The technical solutions required solid foundations, the creation of underground rooms used for storing food supplies or as cells for prisoners, which had a strong impact on relief. The changes in topography by this man-made activity through excavations and reallocations of materials can be identified in point cloud dataset as underground chambers and the pattern model of ruins (Fig. 7).

The complex 3D model of the Princely Church historical monument (Fig. 8) was used for a better visualization and interpretation of medieval architecture in a realistic manner, opening a new perception. This can be a real opportunity to be used in medieval architecture and art research projects for building restoration and preservation as well as for the advertisement of the historical site in media and within the historical museum nearby.
This model can emphasize hidden influence of topography features upon the monument. For example, there is a narrow area bordering the church with altitudes lower than the one recorded in the neighbouring area (Fig. 8). This is explained by the subsidence phenomena which affects especially old buildings by negative slow motion of land under the pressure of constructions. This effect can cause damage to building foundation, water infiltration into walls and, later, fungal spores development. This is the highest risk factor today because it endangers the paintings and interior decorations which can lead to a great loss of historical values.

The upper level of the photogrammetric data processing and product generation is the three-dimensional modelling of the site, including image-matching between ground photos and UAV images. The integration of ground photos with aerial digital imagery into a point cloud is done automatically based on pixel matching for the same area. The proposed methodology drove us to a precise and realistic 3D model of Princely Church monument, which is useful for architectural and historical analysis (Fig. 9).

This 3D reconstruction can be proposed as an unconditional support for architecture with the possibility to establish the location of design elements and to measure volumes and different parameters, including lengths, heights and angles (Cantzler 2003, Apollonio et al. 2013). It allows the drawing of different stages in architectural and historical evolution for the church. Starting from the current models, the restoration can be better managed within the 3D simulation of planned work and assesses the most suitable changes with no physical impact for the monument.

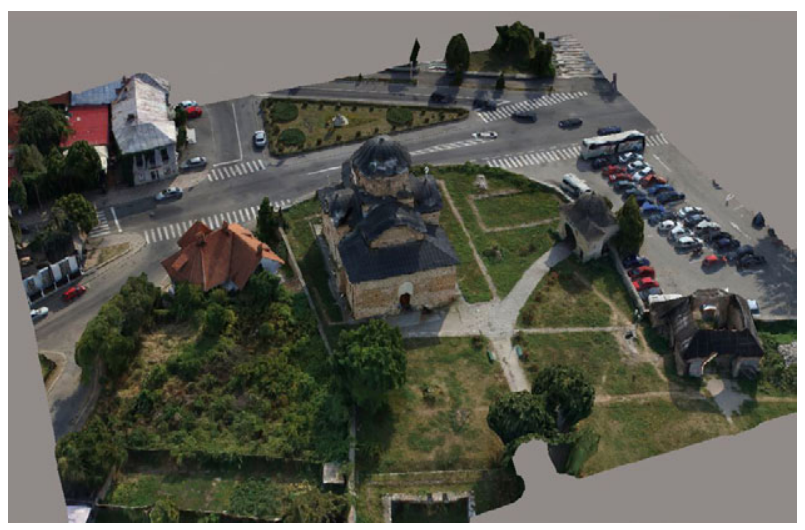

Fig. 10. Panoramic view of 3D model of Curtea de Argeş site. 
This digital representation is suitable to be integrated into new technologies and to be delivered to the general public. It can be accessed for visualization and exploration for a better understanding of the historical significance (Fig. 10). All this data offers support for an improved communication using smart technologies in multimedia advertisements for tourism campaigns and educational purposes.

\section{Conclusion}

The current methodology is based on the integration between photogrammetric workflow and archaeological landmark surveying in a GIS environment. This contributes to the understanding of the strategic significance of the relief on the Princely Court development and its impact on the natural landforms. Curtea de Argeş Princely Court is a typical example of a medieval site superposed on a fluvial landform, totally integrated in the context of the urban development during the last century. Its features can be explored only at high resolution using accurate data and field survey investigation.

UAV technology delivers low cost solution for imagery coverage that can be processed to a point cloud, DEM, orthophotomosaic, which allow landform analysis and site mapping. The introduction of ground photos and the image matching with UAV data enables the 3D architectural reconstruction of the elements of interest, which opens new possibilities for the architectural and historical researches.

The models can be easily integrated in smart multimedia applications for touristic site promotion and educational purposes (2D and 3D).

\section{Acknowledgements}

The research was possible with the help of GISBOX SRL for UAV photogrammetric campaign and data processing.

\section{References}

Adriansyah D., Busu I., Eva H., Muqtada M., 2015. Geoheritage ss the basis for geotourism development: a case study in Jeli District, Kelantan, Malaysia. Geojournal of Tourism and Geosites 15: 25-43.

Aicardi I., Chiabrando F., Grasso N., Lingua A.M., Noardo F., Spanò A., 2016. UAV photogrammetry with oblique images: First analysis on data acquisition and processing. In: International Archives of the Photogrammetry, Remote Sensing and Spatial Information Sciences: 835-842. DOI 10.5194/isprsarchives-XLI-B1-835-2016.

Apollonio F.I., Gaiani M., Sun Z., 2013. 3D modeling and data enrichment in digital reconstruction of architectural heritage. XXIV Int. CIPA Symp. XL-5/W2: 43-48. DOI 10.5194/isprsarchives-XL-5-W2-43-2013.

Bouquet M., 1843. Album Valaque, vues et costumes pittoresques de la Valachie dessinés d'après nature (Wallachian Album, views and picturesque costumes of Wallachia drawn from nature). Imp. Lemercier, Paris.

Cantzler H., 2003. Improving architectural 3D reconstruction by constrained modelling. University of Edinburgh, Edimburgh.

Cârlan I., Dovleac B., 2017. 3D modelling of Arutela Roman Castrum using close-range photogrammetry. Int. J. Conserv. Sci. 8: 35-42.

Chan M.A., Godsey H.S., 2016. Lake Bonneville geosites in the urban landscape: Potential loss of geological heritage. In: Oviatt C.G., Shorder J.F. (eds), Lake Bonneville. A scientific update. Developments in Earth Surface Processes 20: 617-633. DOI 10.1016/B978-0-444-63590-7.00023-8.

Clivaz M., Reynard E., 2017. How to integrate invisible geomorphosites in an inventory: a case study in the Rhone River valley (Switzerland). Geoheritage. DOI 10.1007/ s12371-017-0222-7.

Constantinescu N., 1984. Curtea de Argeş (1200-1400) asupra inceputurilor Țării Româneşti (Curtea de Argeş 1200-1400, at the dawn of Wallachia history). Editura Academiei Republicii Socialiste România, Bucharest.

Curinschi G., 1967. Centrele istorice ale oraşelor (The historical cores of towns). Editura Tehnică, Bucharest.

Dadras M., Shafri H.Z.M., Ahmad N., Pradhan B., Safarpour S., 2014. Six decades of urban growth using remote sensing and GIS in the city of Bandar Abbas, Iran. IOP Conf. Ser. Earth Environ. Sci. 20: 12007. DOI 10.1088/17551315/20/1/012007.

De Wever P., Baudin F., Pereira D., Cornée A., Egoroff G., Page K., 2016. The importance of geosites and heritage stones in cities - a review. Geoheritage. DOI 10.1007/ s12371-016-0210-3

Del Lama E.A., Corte-Bacci D., Martins L., Gloria Motta Garcia M., Dehira K.L., 2015. Urban geotourism and the old bentre of São Paulo City, Brazil. Geoheritage 7: 147-164. DOI 10.1007/s12371-014-0119-7.

Del Monte M., D’Orefice M., Luberti G.M., Marini R., Pica A., Vergari F., 2016. Geomorphological classification of urban landscapes: the case study of Rome (Italy). Journal of Maps 12. DOI 10.1080/17445647.2016.1187977.

Doering M., Blaurock M., Robinson C.T., 2012. Landscape transformation of an Alpine floodplain influenced by humans: Historical analyses from aerial images. Hydrological Processes 26: 3319-3326. DOI 10.1002/hyp.8374.

Erikstad L., Nakrem H.A., Markussen J.A., 2017. Protected geosites in an urban area of Norway. Inventories, values, and management. Geoheritage. DOI 10.1007/s12371-0170223-6.

Jao F.J., Chu H.J., Tseng Y.H., 2014. Historical image registration and land-use land-cover change analysis. Environments 1(2): 181-189. DOI 10.3390/environments1020181 
Mandrut O., 1994. Relieful Subcarpatilor dintre Arges si Argesel (Subcarpathian relief between Arges and Argesel). University of Bucharest, Bucharest.

Martin S., Reynard E., Pellitero Ondicol R., Ghiraldi L., 2014. Multi-scale web mapping for geoheritage visualisation and promotion. Geoheritage 6: 141-148. DOI 10.1007/ s12371-014-0102-3.

Mihai B., Nistor C., Toma L., Săvulescu I., 2016. High resolution landscape change analysis with CORONA KH4B imagery. A case study from Iron Gates Reservoir Area. Environmental Sciences 32: 200-210. DOI 10.1016/j. proenv.2016.03.025.

Mikhail E.M., Bethel J., McGlone J.C., 2001. Introduction to modern photogrammetry. Wiley \& Sons, Chichester.

Nebiker S., Lack N., Deuber M., 2014. Building change detection from historical aerial photographs using dense image matching and object-based image analysis. Remote Sensing 6: 8310-8336. DOI 10.3390/rs6098310.

Nex F., Remondino F., 2014. UAV for 3D mapping applications: A review. Applied Geomatics 6: 1-15 DOI 10.1007/ s12518-013-0120-x.

Osaci-Costache G., 1998. Evolutia orasului Curtea de Arges reflectata in documente cartografice (Evolution of Curtea de Arges city interpreted from cartographic documentes). In: Comunicari de Geografie: 192-197 Editura Universitatii din Bucuresti, Bucharest.

Pelfini M., Bollati I., 2014. Landforms and geomorphosites ongoing changes: Concepts and implications for geoheritage promotion. Quaestiones Geographicae 33: 131-143. DOI 10.2478/quageo-2014-0009.

Pica A., Reynard E., Grangier L., Kaiser C., Ghiraldi L., Perotti L., Del Monte, M., 2017. Geoguides, urban geotourism offer powered by mobile application technology. Geoheritage. 18. DOI 10.1007/s12371-017-0237-0.

Pica A., Vergari F., Fredi P., Del Monte M., 2016. The Aeterna Urbs geomorphological heritage (Rome, Italy). Geoheritage 8: 31-42. DOI 10.1007/s12371-015-0150-3

Pinto A.B.C., Brilha J.B.R., Rios D.C., Rosat, C.S.O., 2011. Urban geotourism in Salvador (Bahia, Brazil) : a strategy for the promotion of geosciences education and geoconservation. In: International Congress of Geotourism Arouca 2011: 29-32.
Reynard E., Pica A., Coratza P., 2017. Urban geomorphological heritage. An overview. Quaestiones geographicae (this volume)

Rodrigues M.L., Freire E., Machado C.R., 2011. Geotourism routes in urban areas: a preliminary approach to the Lisbon geoheritage survey. Geojournal of Tourism and Geosites 8: 281-294.

Ruan R., Ellis E., 2004. An illustrative study on local landscape and its long-term changes based on IKONOS and historical aerial photo. Chinese Geographical Science 14: 162-169. DOI 10.1007/s11769-004-0026-y

Sandu M., 1997. Bazinul Subcarpatic al Argesului. Categorii de risc geomorfologic (Subcarpathian basin of Arges river. Categories of geomorphological risks). Rev. Geogr. 4: 22-26.

Sandu M., 2008. Muscelele Argesului (Piedmont of Arges). In: Badea L. (ed.), Unitatile de Relief Ale Romanie, III: Dealurile Pericarpatice. Editura Ars Docendi, Bucuresti.

Scardozzi G., 2010. The contribution of historical aerial and satellite photos to archaeological and geo-archaeological research: Case studies in Italy and Turkey. Advances in Geosciences 24: 111-123. DOI 10.5194/adgeo-24-111-2010.

Serrano E., Ruiz-Flaño P., 2009. Geomorphosites and geodiversity. In: Reynard E., Coratza P., Regolini-Bissig G. (eds), Geomorphosites. Pfeil, München: 49-61.

Stichelbaut B., 2006. The application of First World War aerial photography to archaeology: the Belgian images. Antiquity 80: 161-172. DOI 10.1017/S0003598X00093339.

Varga K., Szabó S., Szabó G., Dévai G., Tóthmérész B., 2015. Improved land cover mapping using aerial photographs and satellite images. Open Geosciences 7: 15-26. DOI 10.1515/geo-2015-0002.

Werle D., 2016. Early aerial photography and contributions to Digital Earth - The case of the 1921 Halifax air survey mission in Canada. IOP Conf. Ser. Earth Environ. Sci. 34: 12039. DOI 10.1088/1755-1315/34/1/012039.

Zarnowski A., Banaszek A., Banaszek S., 2015. Application of technical measures and software in constructing photorealistic 3D models of historical building using groundbased and aerial (UAV) digital images. Reports on Geodesy and Geoinformatics 99: 54-63. 